\title{
Industrial Waste as Raw Material for Producing Synthetic Wollastonite in Russia
}

\author{
Sofia B. Yarusova, Pavel S. Gordienko, Yogesh C. Sharma, Aleksandr V. Perfilev, and Andrey V. Kozin
}

\begin{abstract}
In this paper we present the results of analysis of the scientific and technical literature concerning the ways of obtaining wollastonite from various calcium and silicon-containing technogenic wastes accumulated on the territory of the Russian Federation. We proposed a method for producing autoclave needle-like wollastonite from waste of boric acid (borogipsa) containing both calcium and silicon constituents. The phase composition and morphology of the products autoclaving borogipsa were studied. It is found that the initial product has a crystalline phase of unreacted calcium sulfate anhydrous, tobermorite and xonotlite. After firing at $1000{ }^{\circ} \mathrm{C}$, the amorphous calcium hydrosilicates are converted to a crystalline phase of wollastonite triclinic modification. The effect of firing temperature on phase composition and morphology of the compounds obtained by autoclave treatment were described. It is shown that with increase of the firing temperature up to $1200{ }^{\circ} \mathrm{C}$ along with a phase change, the composition variation of the particle morphology occurs. It is found that the processing borogipsa to obtain needle-like wollastonite recommended firing temperature should not exceed $1000{ }^{\circ} \mathrm{C}$.
\end{abstract}

Index Terms - Industrial waste, wollastonite, borogypsum.

\section{Problem RevieW}

Main processing properties of wollastonite $\mathrm{Ca}_{6} \mathrm{Si}_{6} \mathrm{O}_{18}$ are high chemical resistance in different media, small specific gravity, unique dielectric properties and low thermal conductivity, as well as environmental friendliness and safety. This fact explains the widespread usage of wollastonite in the production of building materials, paper, paints, plastics, polymer composites and sintered materials, and sorbents for the purification of water. This mineral is an effective substitute for a number of materials like asbestos, kaolin, chalk, talc, titanium dioxide in the production of decorative materials, products on the basis of asbestos-cement, acoustic and thermal insulating materials etc. Wollastonite is widely used as a material of various additives in order to increase their strength, heat resistance, chemical resistance and durability, and to improve the electrical insulating

Manuscript received March 28, 2016; revised July 5, 2016.

Sofia B. Yarusova is with Institute of Chemistry, Far-Eastern Branch of Russian Academy of Sciences; 159 Prospekt 100-letya Vladivostoka, Vladivostok, 690022, Russian Federation. She is also with Vladivostok State University of Economics and Service; 41 Gogolya street, Vladivostok, 690014, Russian Federation (e-mail: yarusova_10@mail.ru).

Pavel S. Gordienko and Aleksandr V. Perfilev are with Institute of Chemistry, Far-Eastern Branch of Russian Academy of Sciences; 159 Prospekt 100-letya Vladivostoka, Vladivostok, 690022, Russian Federation.

Yogesh C. Sharma is with the Department of Chemistry, Indian Institute of Technology (BHU) Varanasi, Varanasi 221005, India.

Andrey V. Kozin is with Far-Eastern Federal University; 8 Sukhanova street, Vladivostok, 690950, Russian Federation. characteristics, reduce the duration of processes in their manufacture, and processing temperature reduction [1], [2]. The wollastonite market report performed by the research group "InfoMine", noted that the first place has got China in terms of production, consumption and export of wollastonite, where production of wollastonite exceeds 300 thousand tons a year. India takes the second place in the world in terms of production of wollastonite, the third - the USA, where production of wollastonite has been going on for over 60 years [3].

In the Russian Federation, despite the growing demand of wollastonite from the number sectors of domestic industry and explored deposits of this mineral, its production is practically absent. In this case the "wollastonite issue" repeatedly mentioned scientists working in the field of materials science, chemical engineering, geology, and economics [4]-[7].

However, the Russian Federation, has a large number of so-called "technogenic deposits" in addition to natural deposits of wollastonite which can be counted as a promising source of raw material for production of synthetic wollastonite. Analysis of ongoing research and existing scientific papers covering the period from the 1970s till today has shown that Russian and former Soviet Union scientists have been actively pursuing and carried out research related to the use of calcium and silicon technogenic waste for wollastonite. They have developed plenty of methods for producing synthetic wollastonite, such as the waste phosphogypsum, belite (nepheline) sludge, phosphoric slag, and waste production of aluminum fluoride. Moreover, in a number of works for the synthesis of wollastonite, two or more kinds of man-made wastes have been used. Some kinds of calcium and silicon waste, and links to a number of scientific works devoted to obtaining wollastonite using them, are given in the Table I.

As it can be seen from the Table I, there is a certain large inventory of technogenic raw material sources for wollastonite production. There is an example below illustrating the basic idea of the report, presented the results of studies on the production of synthetic wollastonite on the basis of waste production of boric acid, whose number in Russia exceeds $50 \mathrm{mln}$ tons.

Since early 2007, the Institute of Chemistry of Far Eastern Branch of the Russian Academy of Sciences in cooperation with the Vladivostok State University of Economics and Service, Far Eastern Federal University and Armenian scientists actively carried out work related to the development of physical and chemical bases of complex processing of boric acid production waste - borogypsum - to give calcium hydrosilicates, wollastonite and potassium 
fertilizers. Borogypsum main components are calcium sulfate dihydrate and amorphous silica. Borogypsum characterized by the following content of the main components, weight percentage: $\mathrm{SiO}_{2}-26-28 ; \mathrm{CaO}-26-28 ; \mathrm{SO}_{4}{ }^{2-}-38-40$; $\mathrm{Fe}_{2} \mathrm{O}_{3}-1.8-2 ; \mathrm{Al}_{2} \mathrm{O}_{3}-0.6-0.8 ; \mathrm{B}_{2} \mathrm{O}_{3}-0.7-1.2 ; \mathrm{MnO}-0.2$; $\mathrm{MgO}-0.1-0.2$. It is from 5 to 5.5 tons of borogypsum can be obtained from 1 ton of boric acid. Borogypsum is of particular interest because its composition contains both calcium and silicon components in an optimum ratio to obtain wollastonite, and therefore requires no additional sources of raw materials for blending initial mixture.

TABLE I: SOME TYPES OF "TECHNOGENIC DEPOSITS" USED FOR THE PRoduction OF SyNTHETIC WOLLASTONITE STUdIES SinCE 1970

\begin{tabular}{|c|c|c|}
\hline $\begin{array}{c}\text { № } \\
\text { item }\end{array}$ & Waste type & Reference \\
\hline \multicolumn{3}{|c|}{ Lime containing waste } \\
\hline 1 & Phosphogypsum & {$[1],[8]-[14]$} \\
\hline 2 & Soda ash waste & {$[15]$} \\
\hline 3 & Waste of carbide calcium separation & {$[16]$} \\
\hline 4 & A mixture of Cretaceous rocks (overburden) & {$[17]$} \\
\hline \multicolumn{3}{|c|}{ Silicon-containing waste } \\
\hline 5 & Aluminum fluoride production waste (silica gel) & {$[8]-[13]$,} \\
\hline 6 & Waste from ferroalloy industry (microsilica) & {$[19]-[21]$} \\
\hline 7 & Ash waste from the combustion of brown coal & {$[22]$} \\
\hline 8 & Calx (crashed glass) & {$[23]$} \\
\hline \multicolumn{3}{|c|}{ Waste containing calcium and silicon } \\
\hline 9 & Belite (nepheline) slurry & {$[21]$,} \\
\hline 10 & Shosphoric slag & {$[36]-[39]$} \\
\hline 11 & \multicolumn{2}{|c|}{ Borogypsum } \\
\hline 12 & & {$[35]$} \\
\hline
\end{tabular}

As a result of research work, the kinetic characteristics of ultrasonic, microwave and autoclave synthesis of calcium silicates from borogypsum were analyzed [37]-[39]. Later studies have been conducted on the effect of additives on the basis of wollastonite obtained in autoclaved borogypsum on the functional properties of fine-grained concrete. Obtained data showed $3.5 \%$ additive based on wollastonite enables to increase the limit of fine-grained concrete compressive strength to $35 \%$ for pressure and up to $50 \%$ for bending, reduce water absorption and increase frost resistance [40].

Following upon researches obtained wollastonite by autoclave method with needle-shaped particles, which is an important aspect to consider when selecting field of application.

\section{EXPERIMENTAL PART}

\section{A. Synthesis of Calcium Silicates}

Borogypsum was mixed with a solution of potassium hydroxide in stoichiometric ratio. Synthesis was carried out in autoclave 4848, Parr Instrument Company (USA) at $220{ }^{\circ} \mathrm{C}$ for 3 hours. After specified time, the resulting mixture was removed from the autoclave, precipitate was washed with distilled water, heated to $60-70{ }^{\circ} \mathrm{C}$, then was separated from the solution by filtration through a paper filter "blue tape" and dried at $85^{\circ} \mathrm{C}$ for several hours.

\section{B. Analysis Methods}

$\mathrm{X}$-ray diffraction patterns were collected on a D8 Advance automatic diffractometer (sample rotation, $\mathrm{CuK \alpha}$ radiation).
Phase compositions were determined using EVA search software and PDF 2 data.

The IR spectra of samples were recorded in the region of 400-2000 $\mathrm{cm}^{-1}$ using a Shimadzu Prestige-21 FTIR Fourier-transform IR spectrometer at room temperature. Samples for recording were ground in an agate mortar to a finely dispersed state and deposited onto a KRS-5 substrate as a suspension in mineral oil.

The morphological characteristics of the samples were studied with a Hitachi S5500 high-resolution scanning electron microscope equipped with an attachment for scanning transmission microscopy and a Thermo Scientific energydispersive spectrometer.

\section{RESULTS AND DISCUSSION}

According to the X-ray diffraction, a part of the synthesized sample detected crystalline phases unreacted anhydrous calcium sulfate $\mathrm{CaSO}_{4}$, tobermorite $\mathrm{Ca}_{5}(\mathrm{OH})_{2} \mathrm{Si}_{6} \mathrm{O}_{16} \cdot 4 \mathrm{H}_{2} \mathrm{O}$ and xonotlite $\mathrm{Ca}_{6}\left[\mathrm{Si}_{6} \mathrm{O}_{17}\right](\mathrm{OH})_{2}$. After sample firing, there was a transition of amorphous calcium hydrosilicates into a crystalline phase of wollastonite of triclinic modification as identified by $\mathrm{X}$-ray diffraction analysis of the sample after calcination at $1000{ }^{\circ} \mathrm{C}$ for 1 hour (Fig. 1). The precipitate obtained by firing at $1000{ }^{\circ} \mathrm{C}$ represents a sample composed of wollastonite phase (with a crystal unit cell parameters a-7.92580; b-7.32020; $c-7.06530 ; \alpha=90.055 ; \beta=95.217 ; \gamma=103.426)$.

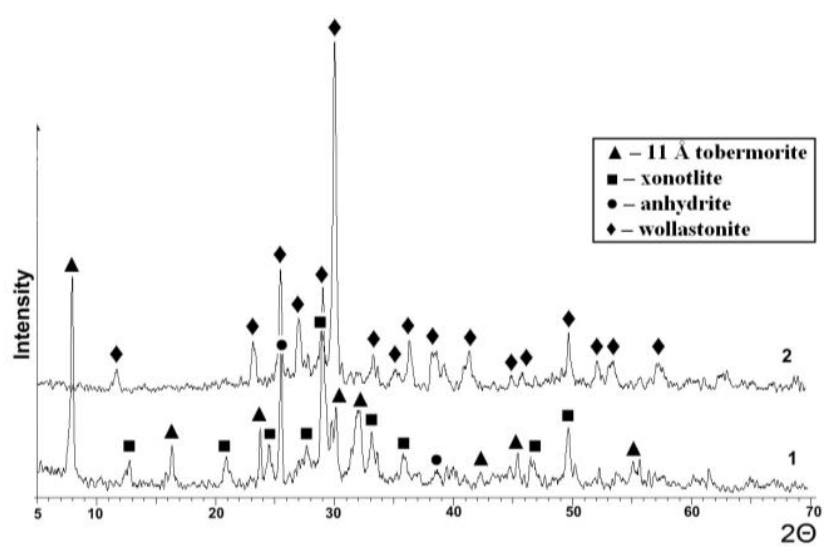

Fig. 1. X-ray diffraction patterns of the synthesized sample: 1 - before firing (initial sample); 2 - after firing at $1000{ }^{\circ} \mathrm{C}$ for $1 \mathrm{~h}$.

Fig. 2 shows the IR spectra of synthesized sample before and after firing at $1000{ }^{\circ} \mathrm{C}$ for $1 \mathrm{~h}$.

According to [41]-[43], it can be seen from the given IR spectra that synthesized calcium silicates are characterized by an intense absorption band produced by the asymmetric vibrations of bridging $\mathrm{Si}-\mathrm{O}-\mathrm{Si}$ bonds and the asymmetric and symmetric vibrations of terminal $\mathrm{Si}-\mathrm{O}$ bonds in the region of $850-1100 \mathrm{~cm}^{-1}$. When the firing temperature is increased to $1000{ }^{\circ} \mathrm{C}$, amorphous calcium silicates (tobermorite and xonotlite) is observed to transition into the crystalline wollastonite phase (spectrum 2). A set of bands in the region of $550-750 \mathrm{~cm}^{-1}$ is assigned to the symmetric vibrations of bridging $\mathrm{Si}-\mathrm{O}-\mathrm{Si}$ bonds in $\left[\mathrm{SiO}_{4}\right]$ tetrahedra. The absorption bands in the low-frequency region of $400-550 \mathrm{~cm}^{-1}$ are due to the bending vibrations of terminal $\mathrm{O}-\mathrm{Si}-\mathrm{O}$ bonds and the vibrations of $\mathrm{Ca}-\mathrm{O}$ bonds in $\left[\mathrm{CaO}_{6}\right]$ 
octahedra [41]-[43]. The absorption band at $1600 \mathrm{~cm}^{-1}$ is due to the bending vibrations of crystallization water [44].

According to the scanning electron microscope, the resulting wollastonite consists of agglomerates of nanoscale particles having predominantly needle-like shape (Fig. 3). Anisotropy factor (L/d) varies from 70 to 140 .

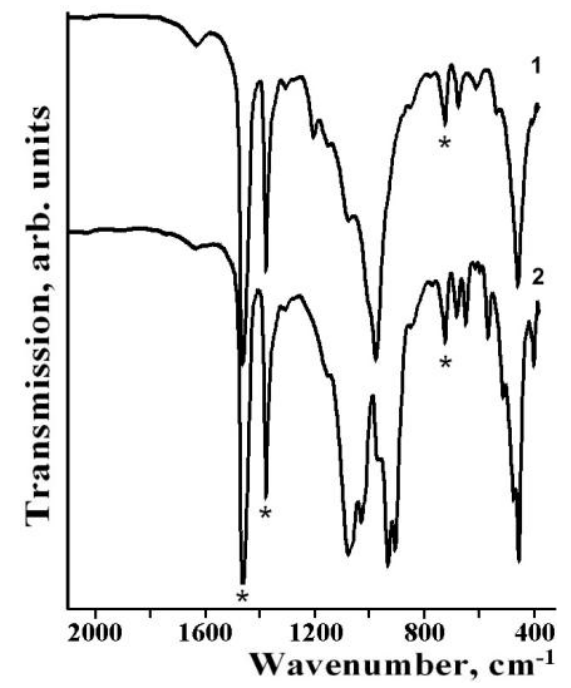

Fig. 2. IR spectra of the synthesized sample: 1 - before firing (initial sample); 2 - after firing at $1000{ }^{\circ} \mathrm{C}$ for $1 \mathrm{~h}$.
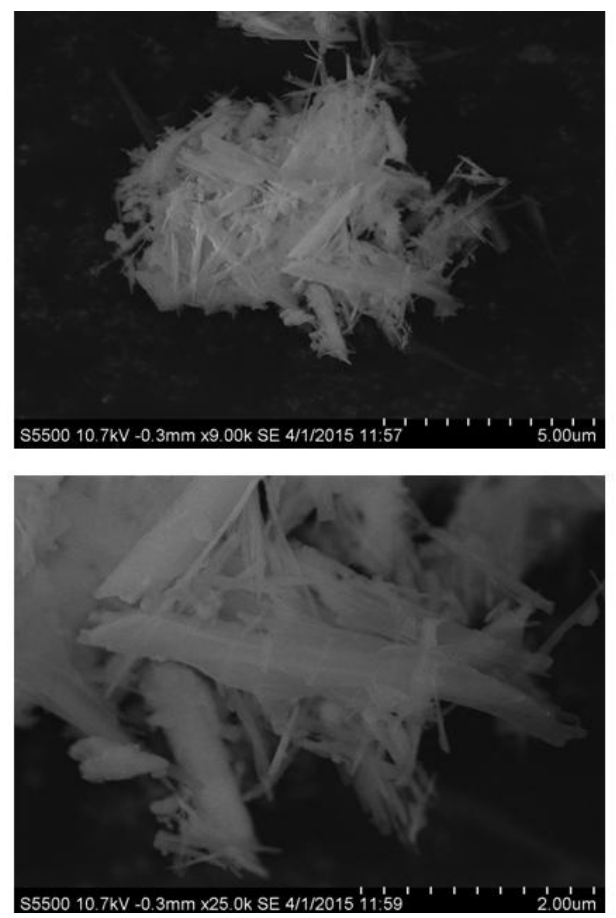

Fig. 3. SEM image of microparticles of wollastonite, the resulting autoclave synthesis from borogypsum.

Table II presents the data on the phase composition of calcium hydrosilicates samples depending on the temperature. This will give specific recommendations in selecting areas of application of the compounds in a variety of industries. This Table also shows the phase composition of the samples as a function of firing temperature.

As seen from the Table II, by firing the samples obtained at 1000 and $1100{ }^{\circ} \mathrm{C}$, phase composition is characterized by the wollastonite triclinic modification, but different crystal lattice parameters, and after firing at $1200{ }^{\circ} \mathrm{C}$, the formation of high temperature polymorph modification of wollastonite (pseudowollastonite $\alpha-\mathrm{CaSiO}_{3}$ ) occurs.

TABLE II: THE PHASE COMPOSITION OF THE SAMPLES AS A FUNCTION OF FIRING TEMPERATURE

\begin{tabular}{|c|c|c|}
\hline $\begin{array}{c}\text { Firing } \\
\text { temperature, }{ }^{\circ} \mathrm{C}\end{array}$ & Phase composition & $\begin{array}{l}\text { Crystal unit cell } \\
\text { parameters }\end{array}$ \\
\hline 1000 & $\begin{array}{l}\text { Wollastonite } \\
\left(\mathrm{CaSiO}_{3}\right)\end{array}$ & $\begin{array}{lr}\text { PDF-2, } & \text { 01-084-0654: } \\
\text { a-7.92580; } & \text { b-7.32020; } \\
c-7.06530 ; & \\
\alpha=90.055 ; & \\
\beta=95.217 ; & \\
\gamma=103.426 & \end{array}$ \\
\hline 1100 & $\begin{array}{l}\text { Wollastonite } \\
\left(\mathrm{CaSiO}_{3}\right)\end{array}$ & $\begin{array}{lr}\text { PDF-2, } & 00-010-0487: \\
\text { a-7.88000; } & \text { b-7.27000; } \\
c-7.03000 ; & \\
\alpha=90.000 ; & \\
\beta=95.217 ; & \\
\gamma=103.200 & \end{array}$ \\
\hline 1200 & $\begin{array}{l}\text { Pseudo- wollastonite } \\
\mathrm{Ca}\left(\mathrm{SiO}_{3}\right)\end{array}$ & $\begin{array}{l}\text { PDF-2, } \quad 01-089-6463: \\
a-11.83220 ; \quad b-6.86240 ; \\
c-10.52970 ; \alpha=90.000 ; \\
\beta=111.245 ; \\
\gamma=90.000\end{array}$ \\
\hline
\end{tabular}

As described above, wollastonite is formed as a result of firing at $1000{ }^{\circ} \mathrm{C}$, consisting mainly of agglomerates of nanoscale particles having a needle-like shape (Fig. 3).

Fig. 4 shows a sample image of the microparticles after firing at $1100{ }^{\circ} \mathrm{C}$.
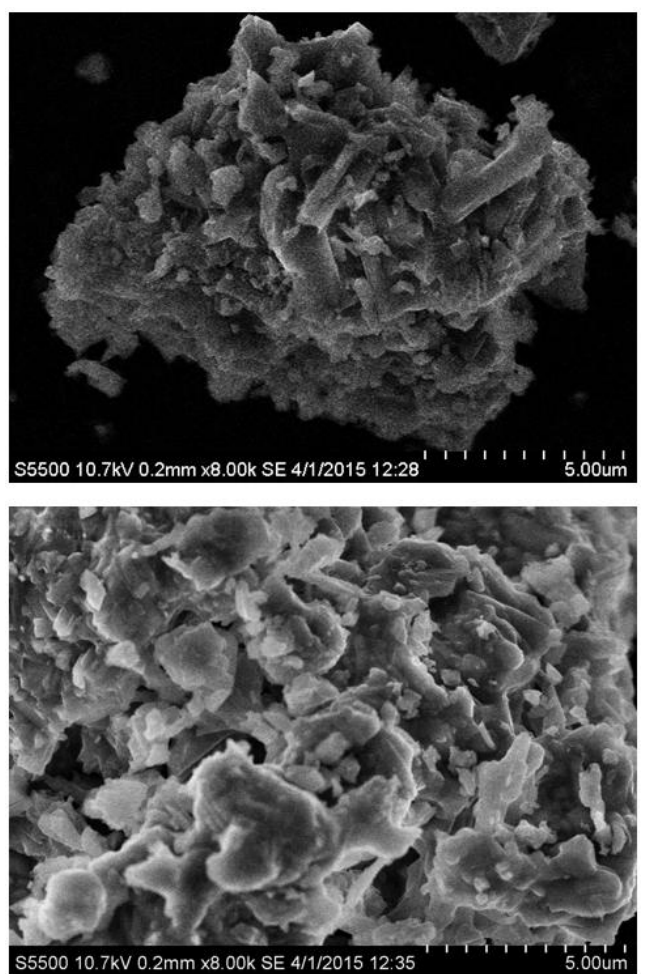

Fig. 4. SEM images of microparticles of wollastonite, the resulting synthesis autoclave, after firing at $1100{ }^{\circ} \mathrm{C}$.

As can be seen from Fig. 4, with an increase in the firing temperature to $1100{ }^{\circ} \mathrm{C}$, there is a change in particle morphology. In particular dense aggregates of particles of various shapes are formed, and the needle-like particles get disappeared.

Fig. 5 shows SEM images of microparticles of a sample, obtained by synthesis autoclave, after firing at $1200{ }^{\circ} \mathrm{C}$. As can be seen from the Fig. 5, as a result of the firing of the sample at $1200{ }^{\circ} \mathrm{C}$, the formation of mostly flat particles with distinct edges occurs. Particle size also increases. Needle-like 
particles was not found.
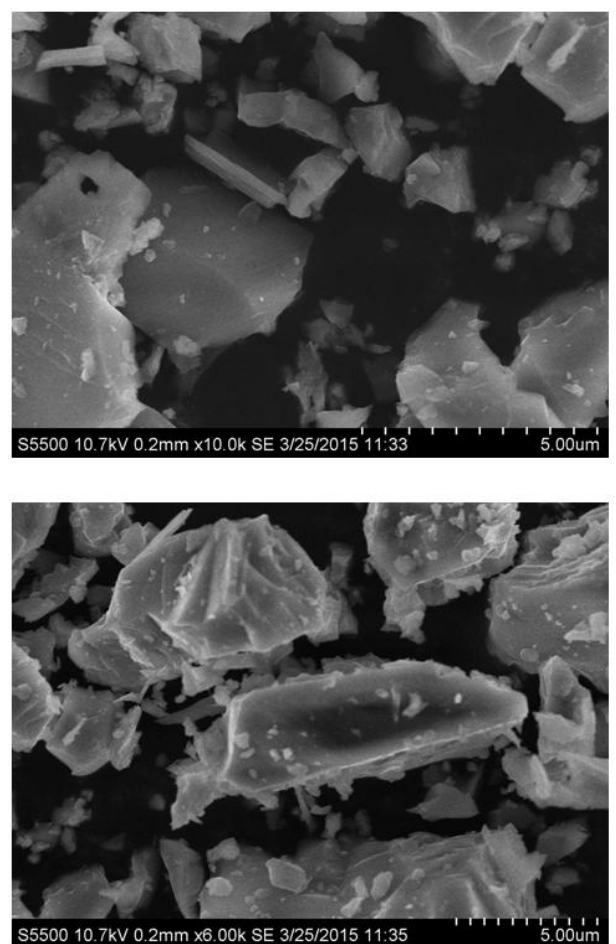

Fig. 5. SEM images of wollastonite microparticles, the resulting synthesis autoclave, after firing at $1200{ }^{\circ} \mathrm{C}$.

This suggests that an increase in the firing temperature to $1200{ }^{\circ} \mathrm{C}$ along with a phase change, the composition variation of the particle morphology occurs. The main features of these changes are the disappearance of the needle-like particles, the appearance of dense particle aggregates of various shapes and particles enlargement. Thus, the borogipsa processing to obtain acicular wollastonite recommended firing temperature should not exceed $1000{ }^{\circ} \mathrm{C}$.

\section{CONCLUSIONS}

Thus, this study provides an overview of the scientific and technical literature, related to the problem of obtaining wollastonite from industrial waste in Russia. In addition, the authors of the work are presented results of own research on the synthesis of wollastonite from industrial waste. The possibility of obtaining needle-like wollastonite on the basis of boric acid production waste, the amount of which in the Far Eastern region of Russia exceeds $50 \mathrm{mln}$ tons, was shown.

The study is advisable to make a conclusion that there are a number of backgrounds in Russia for the production of synthetic wollastonite:

- a wide range of calcium and silicon-containing industrial waste accumulated on the territory of the Russian Federation (nearly in every region) in large quantities;

- the results of carried out extensive research with the involvement of a industrial waste in the process of obtaining wollastonite;

- scientific research results allowing to obtain high quality wollastonite simultaneously from two or more kinds of anthropogenic waste containing calcium and silicon components in an optimum ratio.

All of these conditions contribute to the reduction of Russia's demand for wollastonite raw materials and eliminate the need to import at the same time solving the problem of disposal of waste deposits.

\section{REFERENCES}

[1] V. D. Gladun, L. V. Akateva, N. N. Andreeva, and A. I. Kholkin, "The obtaining and use of synthetic wollastonite from natural and man-made materials," Chemical Technology, 2004, no. 9, pp. 4-11.

[2] V. A. Tyulnin, V. R. Tkach, V. I. Eyrikh and N. P. Starodubtsev, "Wollastonite: A unique mineral for multi-purpose," Moskow: Publishing House "Ore and Metals", 2003, p. 144.

[3] Review of Wollastonite Market in the CIS, 2011, p. 99.

[4] V. D. Gladun, A. I. Kholkin, and L. V. Akateva, "Prospects for production of synthetic wollastonite in Russia," Chemical Technology, 2007, vol. 8, no. 5, pp. 201-204.

[5] Y. V. Eyrikh, "The economic rationale for the development of deposits of wollastonite ores: Abstract of Dis. ... Cand. Econom," Sciences, 2007.

[6] A. I. Gusev, "Problems of wollastonite raw materials in Russia," The Successes of Modern Science, 2014, no. 2, pp. 55-59.

[7] E. N. Plotnikova, "Assessment of the development of wollastonite deposits in geospace," Interexpo GEO-Siberia 2012. VIII Intern. Scientific. Congreve, April 10-20, 2012.

[8] A. I. Kholkin, V. D. Gladun, and L. V. Akateva, "Physical and chemical analysis as a methodological basis of processing of mineral raw materials and obtaining of inorganic materials," Chemical Technology, 2011, vol. 12, no. 8, pp. 449-464.

[9] V. D. Gladun, L. V. Akateva, and A. I. Kholkin, "Synthetic calcium silicates," 2011.

[10] L. V. Akateva, A. E. Baranchikov, V. K. Ivanov, and A. I. Kholkin, "Obtaining calcium silicate with long-fiber (needle) particle structure," Chemical Technology, 2014, vol. 15, no. 11, pp. 646-652.

[11] Pat. 2090501, Russian Federation, IPC ${ }^{6}$ C 01 B 33/24, The way for producing fine wollastonite.

[12] Pat. 2091304, Russian Federation, IPC C 01 B 33/24. A method for producing wollastonite.

[13] Pat. 2213054, Russian Federation, $\mathrm{IPC}^{7}$ C 01 B 33/24. A method for producing a fine particulate calcium silicate (options), fine calcium silicate (options), colored composition.

[14] A. c. 827386, USSR C 01 B 33/24, The way for producing synthetic wollastonite.

[15] A. c. 1126540 A, USSR C 01 B 33/24, The charge for the synthesis of wollastonite.

[16] Pat. 2181105, Russian Federation, IPC C 01 B 33/24. Synthetic wollastonite and its production method.

[17] V. A. Isaev and D. S. Prasolov, "Justification of synthetic wollastonite on Stoilensky Mining and Processing Plant from a mixture of chalk and quartz sand," Mountain Information-Analytical Bulletin, 2012, no. 9 , pp. $158-166$.

[18] A. p. 865794, USSR C 01 B 33/24. A method for producing wollastonite.

[19] Pat. 2380340, Russian Federation, IPC C 04 B 33/24. A method for producing the charge for the synthesis of wollastonite and its composition.

[20] N. P. Karionova, "Wollastonite-containing porous ceramic materials based on compositions of high-silica raw materials with natural and man-made components: Abstract of Dis. ... Cand," Tech. Sciences, 2013, p. 22.

[21] S. A. Antipina, V. I. Vereshchagin, and S.V. Egorov, "Synthesis of wollastonite on the basis of nepheline sludge," Technique and Technology of Silicates, 2010, pp. 28-30.

[22] I. V. Pavlov, V. F. Pavlov, and V. F. Shabanov, "A method for producing wollastonite of ash waste from the combustion of brown coal," Chemical Technology, 2011, vol. 12, no. 4, pp. 193-197.

[23] G. A. Lebedeva and I. S. Yinina, "Production of synthetic wollastonite, based on rocks and man-made materials," Ore-Dressing, 2002, no. 3, pp. 33-36.

[24] A. c. 681018, USSR C 04 B 33/02, The charge for the manufacture of wall ceramic products and the method of its preparation.

[25] A. c. 682449, USSR C 01 B 33/24, The way for producing synthetic wollastonite.

[26] A. c. 694480, USSR C 04 B 35/14; C 04 B 33/13, The charge for the synthesis of wollastonite. 
[27] A. c. 1011514 A, USSR C 01 B 33/24, The method for preparing wollastonite.

[28] A. c. 1331827 A1, USSR C 01 B 33/24, The method for preparing wollastonite.

[29] R. G. Eromasov, E. M. Nikiforova, T. V. Stupko, E. D. Kravtsova, and Y. E. Spektor, "Optimization of technological parameters of producing cladding of ceramic materials based on calcium-silicate technogenic raw materials," Modern Problems of Science and Education, 2012.

[30] A. M. Pogodaev, A. F. Shymanskiy, S. V. Melnikov, and A. M. Ivanova, "Synthesis of wollastonite using man-made materials," Refractories and Technical Ceramics, 2007, no. 7, pp. 44-46.

[31] Pat. 21203, Republic of Kazakhstan, IPC C 01 B 33/24, A method for producing wollastonite.

[32] Pat. 27449. Republic of Kazakhstan, IPC C 01 B 33/24, A method for producing wollastonite.

[33] Pat. 2089527, Russian Federation, IPC C 04 B 35/22; C 04 B 35/653; C 01 B 33/24; C 04 B 5/06, A method for producing wollastonite.

[34] Pat. 25064, Republic of Kazakhstan, IPC C 01 B 33/24, The method for producing fine wollastonite.

[35] V. F. Shabanov, V. F. Pavlov, and N. I. Pavlenko, "Porous wollastonite based on metallurgical slags," Building Materials, 2002.

[36] A. c. 1446129 A1, USSR, C 04 B 35/22, The method for producing synthetic wollastonite and sulfur dioxide.

[37] P. S. Gordienko et al., "Synthesisof calcium silicates from boron-containing waste," Chemical Technology, 2011, vol. 12, no. 3 , pp. 142-147.

[38] P. S. Gordienko et al., "Effect of microwave treatment on the kinetics of the formation and morphology of the calcium hydrosilicates," Journal of Applied Chemistry, 2012, vol. 85, no. 10, pp. 1582-1586.

[39] P. S. Gordienko et al., "Effect of ultrasonic treatment on the kinetics of the formation of calcium silicate of boron-containing technogenic waste," Chemical Technology, 2014, vol. 15, no. 10, pp. 577-581.

[40] P. S. Gordienko et al., "Complex processing of boric acid production waste to produce materials for the building industry," Architecture and Construction of the Far East: Mining Informational and Analytical Bulletin (Scientific and Technical Journal), 2014, pp. 60-66.

[41] A. N. Lazarev, Vibrational Spectra and Structure of Silicates, Leningrad: Nauka, 1968, p. 374.

[42] M. Sitarz, M. Handke, and W. Mozgawa, "Calculations of silicooxygen ring vibration frequencies," Spectrochim. Acta, Part A, 1999, vol. 55, pp. 2831-2837.

[43] E. V. Kalinkina, A. M. Kalinkin, W. Forsling, and V. N. Makarov, "Sorption of atmospheric carbon dioxide and structural changes of $\mathrm{Ca}$ and $\mathrm{Mg}$ silicate minerals during grinding. II. Enstatite, akermanite and wollastonite," Int. J. Miner. Process, 2001, vol. 61, pp. 289-299.

[44] K. Nakamoto, Infrared Spectra of Inorganic and Coordination Compounds, Moscow: Nauka, 1966, p. 411.

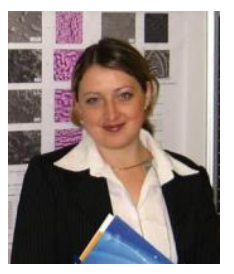

Sofia Yarusova was born on March 10, 1983 in Dalnegorsk (Russia). In 2000 she has graduated (with silver medal) from high school no. 1 of Dalnegorsk. In 2005 she has graduated with honors the Vladivostok State University of Economics and Service (VSUES) on specialty "Ecology". From 2005 to 2008 she was studied at the postgraduate school of the Institute of Chemistry, Far-Eastern Branch of Russian Academy of Sciences on specialty "Physical Chemistry" and worked at the position of a junior research fellow in the laboratory of protective coatings and sea corrosion. In 2010 S. Yarusova defended the thesis "Synthesis of calcium silicates in multicomponent systems and their physical and chemical properties" for the Ph.D. degree.
Since 2011 to the present time she is a research fellow of the laboratory of protective coatings and sea corrosion of the Institute of Chemistry, Far-Eastern Branch of Russian Academy of Sciences. Since 2015 she is the head of the Department of ecology and environmental problems of chemical technology of the VSUES. She is author of more than 100 scientific papers, 10 patents and also a coauthor of two monographs. Research interests: ecology, environment, complex processing of mineral raw materials and industrial waste, obtaining silicate materials (calcium hydrosilicates and wollastonite) for the construction industry and promising sorbents for the purification of aqueous solutions from ions of heavy metals and radionuclides

Dr. Yarusova is a member of the Russian Chemical Society named after D.I. Mendeleev (since 2010), corresponding member of the Russian Ecological Academy (since 2011) and also a member of the editorial board of the "Environmental Chemistry" journal.

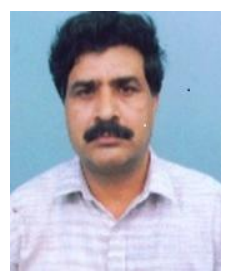

Yogesh C. Sharma is a Professor of Chemistry. He graduated (Ph.D.) from Institute of Technology, Banaras Hindu University, Varanasi, India in 1991 and obtained Doctor of Science (D.Sc.) in Chemistry from CCS University, Meerut, India in 2010. His research interests are synthesis and characterization of nanoadsorbents, and their application for water remediation. He has extensively worked and published on various aspects of water remediation. He has used waste materials, minerals, marophytes, and activated carbons for removal of metallic pollutants, including arsenic and mercury from water and wastewater. He also has worked on synthesis of inorganic adsorptive media for removal of fluorides and nitrates from drinking water. Current research interests of Prof. Sharma are on Bioenergy and Biofuels. His main focus is on synthesis and characterization of biodiesel, bio oils, and catalysts for biodiesel synthesis. Prof Sharma has a good publication record and has an $\mathrm{h}$ index of 40 and more than 6000 citations.

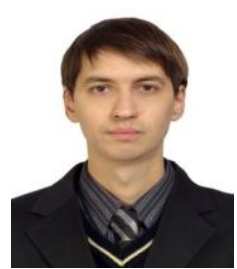

Aleksandr Perfilev was born on March 3, 1984 in Vladivostok (Russia). In 2006 he has graduated with honors the Far-Eastern State Technical University (Vladivostok, Russia) on specialty "Engineer in household machines and equipment". From 2006 to 2009 he was studied at the postgraduate school of the Institute of Chemistry, Far-Eastern Branch of Russian Academy of Sciences (FEB RAS) on specialty "Physical Chemistry". In 2012 A. Perfilev defended the thesis "Obtaining and characteristics of organo-mineral hydrophobic adsorbents on the basis of natural aluminosilicates" for the Ph.D. degree.

He held a position of a Junior Research Fellow (2009-2013), Research Fellow (2013-2014) of the Institute of Chemistry, FEB RAS. Now he is a Senior Research Fellow of the Engineering and technological center of the Institute of Chemistry, FEB RAS. Since 2012 to the present time he reads lectures at the Far-Eastern Federal University. Lecture courses: Water treatment, Drainage systems and sewage treatment, Environmental technologies, Technical ecology. He is author of more than 50 scientific publications. Research interests: complex sewage treatment, highly porous materials and adsorbents, natural aluminosilicates, sorption technologies, water treatment

Dr. Perfilev is a member of the International Water Association, the Russian Chemical Society named after D.I. Mendeleev and a corresponding member of Russian Academy of Ecology. 